\title{
Champagne, a dominant color dilution of horses
}

\author{
DP Sponenberg ${ }^{1}$, AT Bowling ${ }^{2}$ \\ ${ }^{1}$ Department of Biosciences and Pathobiology, Virginia-Maryland Regional College \\ of Veterinary Medicine, Virginia Tech, Blacksburg, VA 24061; \\ 2 Veterinary Genetics Laboratory, School of Veterinary Medicine, \\ University of California at Davis, Davis, CA 95616-8744, USA
}

(Received 3 June 1996; accepted 2 July 1996)

\begin{abstract}
Summary - Champagne dilution of horses results in a group of pale colors which have mottled dusky skin and amber eyes. Body color varies from light brown to gold or cream. Eye color of champagne foals is blue, and darkens to amber with age. The mating of champagne to nonchampagne horses resulted in 54 champagne and 40 nonchampagne foals. These results are consistent with a dominant gene $\left(X^{2}=2.1,1 d f, P>0.1\right)$. This dilution is proposed as due to the champagne allele $\left(C h^{C}\right)$ at the Champagne (Ch) locus. This allele dilutes black to pale brown with dark brown points, dilutes bay to yellow with brown points, and dilutes chestnut to gold or yellow with yellow or pale points.
\end{abstract}

horse / genetics / coat color / champagne dilution

Résumé - Champagne : un gène dominant de dilution des couleurs chez le cheval. Chez le cheval, le phénomène de dilution des couleurs appelé «Champagne» produit un ensemble de couleurs claires allant avec une peau noirâtre tachetée et des yeux couleur d'ambre. La couleur du corps va de brun clair à or ou crème. La couleur de l'œil des poulains champagne est bleue et s'assombrit vers l'ambre avec l'âge. Des accouplements de champagne avec des non-champagne ont donné 54 poulains champagne et 40 non-champagne, ce qui s'accorde avec l'hypothèse d'un gène dominant $\left(\chi^{2}=2,1, \mathrm{p}>0,10\right)$. Il est proposé que le gène responsable de cette dilution soit considéré comme l'allèle champagne $\left(\mathrm{Ch}^{\mathrm{c}}\right)$ au locus Champagne $(\mathrm{Ch})$. Cet allèle dilue le noir en brun clair à points bruns foncés, le bai en jaune à points bruns, et l'alezan en or ou jaune à points jaunes ou clairs.

cheval / génétique / couleur de la robe / dilution champagne

\section{INTRODUCTION}

Dilution of color in horses is associated with several different genetic mechanisms, and each mechanism results in a distinct group of colors (Sponenberg and Beaver, 1983). Early work confused some of these mechanisms, and attributed the actions of two loci to a single locus (Castle and King, 1951; Castle and Singleton, 1961; 
Salisbury and Britton, 1941; Singleton and Bond, 1966). The present understanding of horse color genetics is that dilution is accomplished by three distinct genetic mechanisms (Castle and Smith, 1953; Adalsteinsson, 1974; Van Vleck and Davitt, 1977; Adalsteinsson, 1978; Sponenberg and Beaver, 1983; Craig and Van Vleck, 1985; Lauvergne et al, 1991). This paper provides evidence of a fourth color dilution locus for the horse.

The cremello allele at the Albino locus behaves as an incomplete dominant (Adalsteinsson, 1974). The result of the heterozygous state is that phaeomelanin is lightened from red to yellow, and eumelanin is unchanged. Bay is therefore diluted to buckskin, chestnut to palomino, and black is either unchanged or diluted vary subtly to smoky. The result of the homozygous state is that both phaeomelanin and eumelanin are changed to cream. The skin is pink, and the eyes are blue. On any base color the homozygous state results in cream, although subtle differences from different base colors may persist on some horses. The cremello allele, on its own, does not cause the distinctive striping patterns which are characteristic of another equine dilution locus.

The dun allele at the Dun locus results in the linebacked dun group of horse colors. It is a dominant allele, with identical appearance of heterozygous and homozygous horses (Adalsteinsson 1974, 1978; Van Vleck and Davitt, 1977; Craig and Van Vleck, 1985). The dun allele dilutes phaeomelanin from red to tan or light red, and eumelanin from black to pale beige or blue. The dun allele has minimal dilution effect on the mane, tail, and lower legs. Distinctive stripes down the back, over the withers, and on the legs are also characteristic of the dun colors. As a result of the dun allele, bay is changed to zebra dun, chestnut is changed to red dun, and black is changed to grullo. The actions of dun and cremello are not additive, so that horses with both alleles are only subtly different from those with only one or the other. The horses with both alleles tend to retain the striping associated with dun, and the color is diluted to the maximal extent of either the dun or the cremello allele. Bay is changed to light gold or yellow zebra dun, chestnut to linebacked palomino, and black to grullo. Horses that are homozygous for cremello and also have dun are usually cream colored with striping typical of duns.

The silver dapple allele at the Silver Dapple locus is a third genetic mechanism for dilution of horse color (Castle and Smith, 1953). The silver dapple allele is dominant, and heterozygous and homozygous horses are similar. Phaeomelanin is not conspicuously changed. Eumelanin is diluted to pale sepia. The dilution is greatest in mane, tail, and lower leg. The result on black is silver dapple, the classic form of which is a dappled sepia with very pale mane, tail and lower leg. The action of the silver dapple allele is variable, though, and sometimes its presence is associated with only minimal dilution of eumelanin. Bay is changed to red silver, which retains the red body of bays but has typical changes associated with the silver dapple allele in the mane, tail and legs. Chestnut is changed minimally, if at all, because chestnut phenotypes are phaeomelanic, and the silver dapple allele therefore can have no action.

A group of horse colors that is distinct from the three previous dilute color groups consists of horses with amber eyes (which are blue a birth and then darken) and light colors all of which tend to have a bright metallic sheen. Horses with these colors are sometimes born a dark color, which then lightens with age. This is the 
reverse of most colors of horses (Sponenberg and Beaver, 1983), and contributes to the confusion surrounding these colors. The skin of these horses is dusky pink with dark mottling. This skin color is darker than that of the skin of horses homozygous for cremello and is lighter than the skin of horses with dark color or with dilute color from the other three genetic mechanisms. The colors of this group lack the striping typical of dun horses. This group of colors occurs in a number of breeds as a rare variant.

One of the colors within this group of dilute colors is metallic light brown with darker brown mane and tail, which is the color called champagne by Tennessee Walking Horse breeders. In the past this color has been registered as buckskin or chestnut, probably for lack of a suitable alternative designation by registration authorities. The champagne color does not fit the definition of either buckskin or chestnut. A second variant within the group has a yellow body and brown mane, tail, and lower legs. This variant is frequently registered as buckskin despite the brown (rather than black) mane, tail and legs and the eye and skin characteristics typical of the champagne group of colors. A third variant has a gold or yellow body and legs, and light gold or flaxen mane and tail. This color is frequently registered as palomino although these horses have the amber eyes and mottled dusky pink skin associated with the champagne color group, unlike the palominos arising from the cremello allele. In addition to their occurrence in the Tennesse Walking Horse, these colors have been noticed in Spanish Mustangs and ponies of uncertain breeding. The group of colors including champagne was studied in order to document their mode of inheritance.

\section{MATERIALS AND METHODS}

The complete results of mating individual champagne dilute stallions and mares were available, and are presented in table I. These included several Tennessee Walking Horses, and one Spanish Mustang. The matings were all to nondilute mates. The production records of other individual horses with the champagne allele were studied to determine the colors resulting from the presence of the champagne allele with various background color genotypes. This included horses for which complete records were not available, and these records are presented in tables II and III.

\section{RESULTS AND DISCUSSION}

The matings from champagne dilute horses for which complete data were available produced 54 champagne and 40 nonchampagne foals. Under the hypothesis that the champagne allele is dominant, $X^{2}=2.1,1 d f, P>0.1$. This allele is proposed as the champagne allele at the Champagne locus.

All horses that produced brown foals with brown points (the champagne color) also produced black foals, indicating that they had genotypes capable of producing black foals. The champagne color was never produced by horses who failed to produce black foals. The mating of champagne horses to black mates produced six champagne and five black foals. These findings are consistent with champagne color being the result of the champagne allele on an otherwise black background. 
Table I. Results of mating champagne dilute horses to dark mates, complete records available.

\begin{tabular}{|c|c|c|c|c|c|c|}
\hline \multirow[t]{3}{*}{ Parental color } & \multicolumn{6}{|c|}{ Foal color } \\
\hline & \multicolumn{3}{|c|}{ Nondilute } & \multicolumn{3}{|c|}{ Dilute } \\
\hline & Black & Bay & Chestnut & Champagne & $\begin{array}{l}\text { Yellow/brown } \\
\text { points }\end{array}$ & $\begin{array}{l}\text { Gold/pale } \\
\text { points }\end{array}$ \\
\hline \multicolumn{7}{|l|}{ Champagne } \\
\hline Black & 5 & 0 & 0 & 6 & 0 & 0 \\
\hline Bay & 1 & 1 & 0 & 7 & 1 & 0 \\
\hline Chestnut & 9 & 1 & 0 & 6 & 1 & 1 \\
\hline \multicolumn{7}{|c|}{ Yellow/brown points } \\
\hline Black & 4 & 4 & 0 & 2 & 6 & 0 \\
\hline Bay & 0 & 2 & 1 & 0 & 2 & 3 \\
\hline Chestnut & 3 & 2 & 2 & 1 & 4 & 3 \\
\hline \multicolumn{7}{|c|}{ Gold/pale points } \\
\hline Black & 0 & 2 & 2 & 0 & 4 & 1 \\
\hline Bay & 0 & 0 & 0 & 0 & 1 & 1 \\
\hline Chestnut & 0 & 0 & 1 & 0 & 0 & 4 \\
\hline Subtotal & 22 & 12 & 6 & 22 & 19 & 13 \\
\hline Total & & 40 & & & 54 & \\
\hline
\end{tabular}

Table II. Results of mating champagne dilute horses to dark mates, incomplete records available.

\begin{tabular}{|c|c|c|c|c|c|c|}
\hline \multirow[t]{3}{*}{ Parental color } & \multicolumn{6}{|c|}{ Foal color } \\
\hline & \multicolumn{3}{|c|}{ Nondilute } & \multicolumn{3}{|c|}{ Dilute } \\
\hline & Black & Bay & Chestnut & Champagne & $\begin{array}{l}\text { Yellow/brown } \\
\text { points }\end{array}$ & $\begin{array}{l}\text { Gold/pale } \\
\text { points }\end{array}$ \\
\hline \multicolumn{7}{|l|}{ Champagne } \\
\hline Black & 2 & 0 & 0 & 2 & 0 & 0 \\
\hline Bay & 0 & 0 & 0 & 0 & 0 & 0 \\
\hline Chestnut & 0 & 0 & 0 & 0 & 0 & 1 \\
\hline \multicolumn{7}{|c|}{ Yellow/brown points } \\
\hline Black & 0 & 0 & 0 & 0 & 0 & 0 \\
\hline Bay & 0 & 0 & 0 & 0 & 0 & 0 \\
\hline Chestnut & 0 & 0 & 0 & 0 & 0 & 0 \\
\hline \multicolumn{7}{|c|}{ Gold/pale points } \\
\hline Black & 3 & 2 & 1 & 1 & 2 & 6 \\
\hline Bay & 1 & 2 & 4 & 0 & 6 & 6 \\
\hline Chestnut & 0 & 0 & 32 & 0 & 0 & 41 \\
\hline Subtotal & 6 & 4 & 37 & 1 & 10 & 54 \\
\hline Total & & 47 & & & 65 & \\
\hline
\end{tabular}


Table III. Results of mating champagne dilute horses to light-colored mates, incomplete records available.

\begin{tabular}{|c|c|c|c|c|c|c|c|c|c|}
\hline \multirow[t]{3}{*}{ Parental color } & \multicolumn{9}{|c|}{ Foal color } \\
\hline & \multicolumn{4}{|c|}{ Nondilute } & \multicolumn{5}{|c|}{ Dilute } \\
\hline & Smoky & Black & Bay & Chestnut & Palomino & Champagne & $\begin{array}{l}\text { Yellow/ } \\
\text { brown } \\
\text { points }\end{array}$ & $\begin{array}{l}\text { Gold/ } \\
\text { pale } \\
\text { points }\end{array}$ & Ivory \\
\hline \multicolumn{10}{|l|}{ Champagne } \\
\hline Champagne & 0 & 0 & 0 & 0 & 0 & 0 & 0 & 15 & 0 \\
\hline Palomino & 1 & 0 & 1 & 1 & 4 & 3 & 3 & 3 & 3 \\
\hline Buckskin & 0 & 0 & 0 & 0 & 0 & 0 & 0 & 1 & 0 \\
\hline
\end{tabular}

Parental champagne-colored horses in this table include all colors with the champagne allele (champagne, yellow with brown points, and gold with pale points variants).

Horses with gold body color and yellow or white manes and tails consistently reproduced this color or chestnut following mating to chestnut mates. This is consistent with the gold color resulting from the action of the champagne allele on an otherwise chestnut background.

Horses with yellow body color and brown points only were produced by matings that could also produce bay genotypes, and it is likely that the yellow with brown points color results from the action of the champagne allele on an otherwise bay background.

In some instances horses with gold bodies and light manes and tails were mated to palomino mates. Some of the resulting foals were ivory or cream colored, with mottled dusky skin and dark bluish green eyes. One such ivory foal was mated to a chestnut mare and reproduced the ivory color. The ivory color is probably the result of the heterozygous condition fo both the champagne and the cremello alleles. If this is true, then these two dilutions are additive. Extensive breeding tests have not yet been accomplished, but the reproduction of the ivory color from a chestnut mare indicates that the two alleles are not at the same locus, since they appear to be segregating independently.

Instances in which two champagne-colored horses were mated to one another were relatively rare, and only occurred with horses for which complete production records were unavailable. As a result, the color of homozygotes is undocumented. In all cases of champagne-to-champagne matings, the specific color mated together was the gold type with pale points. These matings produced 15 foals, all of which were gold. The consistent production of the gold color suggests that the homozygous condition of the champagne allele does not result in more extensive dilution than does the heterozygous condition, which argues against an interpretation of the champagne allele as an incomplete dominant. The lack of nondilute horses from these matings is an indication that perhaps not all foals are reported. If this is the case, then extensively diluted foals may well have not been reported. 
The champagne allele is dominant, and dilutes both phaeomelanin and eumelanin. Eumelanin is diluted most on the body, and less on the legs, mane, and tail. Phaeomelanin is diluted to yellow or gold. The result of champagne on a black background is the original champagne color, which is a pale brown horse with darker brown mane, tail, and legs. This is the most widely recognized of the group, mostly because it is difficult to confuse this color with any other horse color. The result of champagne on a bay background is yellow with brown mane, tail and legs. These horses are frequently registered as buckskin, although the usual definition of buckskin describes those horses whose color arises from the cremello allele, and which have black manes, tails and legs, and dark skin, with yellow body color. The result of champagne on chestnut is a golden body and mane and tail which are either a similar gold color or nearly white. This gold color is easy to confuse with the usual palomino arising from the cremello allele, although the skin and eye characteristics are distinct. The results of combining the champagne allele with other base colors are less certain, but the effect of champagne on palomino is probably ivory, which retains the skin and eye characteristics of the champagne group but is otherwise similar to creams that are homozygous for cremello.

\section{ACKNOWLEDGMENTS}

The authors gratefully acknowledge the valuable work and interest of B Kincade, L Nutter, $\mathrm{S}$ Batteatte and L Howland; and their sharing of data for this report.

\section{REFERENCES}

Adalsteinsson S (1974) Inheritance of the palomino color in Icelandic horses. $J$ Hered 65, $15-20$

Adalsteinsson S (1978) Inheritance of yellow dun and blue dun in the Icelandic toelter horse. $J$ Hered $69,146-148$

Castle WE, King FL (1951) New evidence on the genetics of the palomino horse. $J$ Hered $42,60-64$

Castle WE, Singleton WR (1961) The palomino horse. Genetics 46, 1143-1150

Castle WE, Smith FH (1953) Silver dapple, a unique color variety among Shetland ponies. $J$ Hered 44, 139-146

Craig L, Van Vleck LD (1985) Evidence for inheritance of red dun dilution in the horse. $J$ Hered 76, 138-139

Lauvergne JJ, Silvestrelli M, Langlois B, Renieri C, Poirel D, Antaldi GGV (1991) A new scheme for describing horse coat colour. Livest Prod Sci 27, 219-229

Salisbury GW, Britton JM (1941) The inheritance of equine color: II. The dilutes, with special reference to the palomino. $J$ Hered $32,255-260$

Singleton WR, Bond QC (1966) An allele necessary for dilute coat color in horses. $J$ Hered $57,74-77$

Sponenberg DP, Beaver BV (1983) Horse Color. Texas A\&M University Press, College Station, TX

Van Vleck LD, Davitt M (1977) Confirmation of a gene for dominant dilution of horse colors. $J$ Hered $68,280-282$ 